the 123 patients in our study were thought to have died due to a port-related bacteremia. Both were patients with acquired immunodeficiency syndrome and a high degree of immunosuppression (CD4 counts of 41 and 58 cells $/ \mathrm{mm}^{3}$ at the time of device implantation). Excluding these two cases, nearly two thirds (21) of the remaining 32 infections did not require removal of the PAS-Port device to treat infection. In 6 of the 11 cases where the device was removed, infection was due to $S$ aureus.

A limitation of our study was that detailed information about the frequency of device access was not available from the medical records. More frequent PAS-Port access could potentially elevate a patient's risk of infection, and frequency of access may vary greatly between different underlying illnesses, depending on treatment regimens. In addition, for certain underlying oncological diagnoses, there were very few patients, which limited the usefulness of comparisons between underlying illness groups.

In summary, our study provides useful information regarding the risk and rate of catheter-associated infections related to the use of a long-term implantable vascular access device (PAS-Port), especially among HIV-infected individuals. While infections occurred in a quarter of patients, the overall infection rate per 1,000 device days was relatively low. The majority of infections were due to grampositive bacteria. The specific underlying illness may be an important predictor of the risk of infection in patients with long-term venous access devices.

\section{REFERENCES}

1. Kahn ML, Barboza RD, King GA, Heisel JE. Initial experience with percutaneous placement of the PAS Port implantable venous access device. Journal of Vascular and Interventional Radiology 1992;3:459-461.

2. Foley MJ. Radiologic placement of long-term central venous peripheral access system ports (PAS Port): results in 150 patients. Journal of Vascular and Interventional Radiology 1995;6:255-262.

3. Rubenstein EB, Fender A, Rolston KVI, Elting IS, Prasco P, Paimer J, et al. Vascular access by physician assistants: evaluation of an implantable peripheral port system in cancer patients. J Clin Oncol 1995;13(6): 1513-1519.

4. Brant-Zawadzki M, Anthony M, Mercer EC. Implantation of P.A.S. port venous access device in the forearm under fluoroscopic guidance. $A J R$ 1993;160:1127-1128.

5. Lundberg G, Wahlberg E, Rickberg A, Olofsson P. PAS-Port: a new implantable vascular access device for arm placement: experiences from the first two years. Eur I Surg 1995;161:323-326.

6. Maki DG. Pathogenesis, prevention, and management of infections due to intravascular devices used for infusion therapy. In: Bisno $\mathrm{AL}$, Waldvogel FA, eds. Infections Associated With Indwelling Medical Devices. 2nd ed. Washington, DC: American Society for Microbiology; 1994:155-212.

7. Norwood S, Ruby A, Civetta J, Cortes V. Catheter-related infections and associated septicemia. Chest 1991;99:968-975.

8. Pearson ML, Hospital Infection Control Practices Advisory Committee. Guideline for prevention of intravascular-device-related infections. Infect Control Hosp Epidemiol 1996;17:438-473.

9. Groeger JS, Lucas AB, Thaler HT, Friedlander-Klar H, Brown AE, Kiehn TE, et al. Infectious morbidity associated with long-term use of venous access devices in patients with cancer. Ann Intern Med 1993;119: 1168-1174.

10. Johnson JA, Didlake RH. Peripherally-placed central venous access ports: clinical and laboratory observations. Am Surg 1994;60(12):915-919.

11. Garner JS, Jarvis WR, Emori TG, Horan TC, Hughes JM. CDC definitions for nosocomial infections, 1988 Am J Infect Control 1988;16:128-140.

12. Gilbert DN, Dworkin RJ, Raber SR, Leggett JE. Outpatient parenteral antimicrobial-drug therapy. $N$ Engl J Med 1997;337:829-838.

13. Skiest DJ, Grant P, Keiser PP. Nontunneled central venous catheters in patients with AIDS are associated with a low infection rate. J Acquir Immune Defic Syndr Hum Retrovirol 1998;17:220-226.

14. Dega H, Eliaszewicz M, Gisselbrecht M, Fleury J, Pialoux G, Janssen B, et al. Infections associated with totally implantable venous access devices (TIVAD) in human immunodeficiency virus-infected patients. $J$ Acquir Immune Defic Syndr Hum Retrovirol 1996;13:146-154.

15. Sweed M, Guenter P, Lucente K, Turner JL, Weingarten MS. Long-term central venous catheters in patients with acquired immunodeficiency syndrome. Am I Infect Control 1995;23:194-199.

16. Raviglione MC, Battan R, Pablos-Mendez A, Aceves-Casillas P, Mullen MP, Taranta A Infections associated with Hickman catheters in patients with acquired immunodeficiency syndrome. Am J Med 1989;86:780-786.

17. Mukau L, Talamini MA, Sitzmann JV, Burns RC, McGuire ME. Longterm central venous access vs other home therapies: complications in patients with acquired immunodeficiency syndrome. Journal of Parenteral and Enteral Nutrition 1992;16:455-459.

18. Stanley HD, Charlebois E, Harb G, Jacobson MA. Central venous catheter infections in AIDS patients receiving treatment for cytomegalovirus disease. J Acquir Immune Defic Syndr Hum Retrovirol 1994;7:272-278.

19. Skoutelis AT, Murphy RL, MacDonell KB, VonRoenn JH, Sterkel CD, Phair JP. Indwelling central venous catheter infections in patients with acquired immune deficiency syndrome. J Acquir Immune Defic Syndr Hum Retrovirol 1990;3:335-342.

20. Widmer AF. Intravenous-related infections. In: Wenzel RP. Prevention and Control of Nosocomial Infections. 3rd edition. Baltimore, MD: Williams and Wilkins; 1997:777,794.

\title{
Vancomycin-Resistant Enterococci and Biomaterial Surfaces
}

\section{Gina Pugliese, RN, MS Martin S. Favero, PhD}

Enterococci are a frequent cause of nosocomial infections and often are found adherent to indwelling catheters. Concern about such device-associated infections has increased with the appearance of vancomycin-resistant (VR) enterococci. However, the possible influence of vancomycin resistance in the pathogenesis of biomaterial-centered infection has not yet been assessed. Using polyethylene terephthalate (PET) disks as model surfaces, $\mathrm{Su}$ and coinvestigators from Baylor College of Medicine, Houston, Texas, evaluated possible differences in the adherence and persistence of vancomycin-sensitive (VS) and VR strains of Enterococcus faecium and Enterococcus faecalis on biomaterial surfaces in vitro and in vivo. The results indicated that (1) as expected, the clearance of free VR and VS organisms after intraperitoneal injection into normal mice is equally efficient; (2) in vitro, VR bacteria are roughly twice as adherent to plasma-coated PET surfaces as are VS organisms; (3) however, in vivo persistence of VS organisms preadherent to biomaterial implants is 5 - to 10 -fold better than that of preadherent VR organisms. The authors conclude that a discrete change in bacterial cell-wall composition between VR and VS enterococci may contribute to the substantial differences in bacterial adhesion and survival of adherent organisms.

FROM: Su SH, Eaton JW, Venezia RA, Tang L. Interactions of vancomycin resistant enterococci with biomaterial surfaces. ASAIO J 1998; 44:770-775. 